\title{
Tlaxcala and Pátzcuaro, Mexico: Urban Designs to Reflect and Reinforce Concierto Urbano
}

\author{
Mark Lindsay
}

Independent Researcher, USA

Copyright $(2016$ by authors, all rights reserved. Authors agree that this article remains permanently open access under the terms of the Creative Commons Attribution License 4.0 International License

\begin{abstract}
Sixteenth-century Spaniards believed that their modular grid, defined by architecture, implanted their concept of ideal urban culture, or politica humana, in new cities in the New World. The ordered morphology with compact lots and central plaza created a concierto, or harmonious accordance, among the residents, both encomenderos and feudal tributaries. Many were superimposed over imposing precolonial urban/ ceremonial centers. At actual conquests, non-European centers were typically demolished, erasing the memory of the old culture. In many others, selected patterns were retained, recognizing the precolonial cultural origins and significance. This essay compares colonial urban designs in two examples in Mexico, both capitals of major Mesoamerican allies: Pátzcuaro was a former royal Purépecha capital, later abandoned; Tlaxcala was a confederation of four principalities atop a tall mountain chain, heavily fortified to resist Aztecs, where the sons of the old nobility built a new city center in the level valley below. The colonial urban designs consciously recognized the non-European origins and suggest images of colonial acceptance of, and accordance with, the old culture. They expand understanding of cultural interweaving which Mexican scholars cite in their studies.
\end{abstract}

Keywords Pátzcuaro, Tlaxcala, Colonial Urban Design in Mexico / New Spain

\section{Introduction}

Spaniards in the sixteenth and seventeenth centuries believed that a modular urban grid, defined by architecture, implanted their concept of ideal urban culture, or politica humana, in the wave of new towns and cities which they founded in the continental New World. It was further reinforced by construction of imposing structures which defined the town centers, often cited as ennobling them. The ordered morphology with compact lots and central plaza created a concierto, or harmonious accordance, among the residents, both encomenderos and feudal tributaries. Images of urban order generated social bonding among residents which facilitated commerce, elected government, and acceptance and participation in the new religious faith. The term requires analysis for a twenty-first century researcher. A synonym for the term concierto is de acuerdo, cited in a Spanish/English dictionary. The scholar Durston cites it as a reference to a "harmonious community." [1]

The social interaction in that "harmonious community" was generated by ordered city plans defined by central plazas, and compact neighborhoods with houses aligning gridded streets. By the 1520s that perception of order was linked to the modular chess-board grid pattern. It was of course still a late-medieval feudal society, in which people below the hidalgo social status owed feudal tributes of labor and goods. The concepts appeared in chronicles by the second decade of the sixteenth-century; it was not cited in the founding of Santo Domingo at its second site in c. 1502, suggesting that the concept evolved during the first decades of that century.

Spaniards encountered different traditions of city-building as they advanced their rule in many parts of the continental Americas. Most were complex groupings of major temples with residential structures for the rulers and the priests of the old religions. The massive structures were often aligned to significant astronomical alignments, which reflected a belief that their dirty were linked with the cosmos. Non-elite families typically lived in small rural settlements, which Spaniards saw as scattered, or derramados, without the bonds of a European-style urban culture. The friar Mendieta in the late sixteenth century cited rural settlements in Tlaxcala: They lacked "Christian religious doctrine, good government and an urban culture, which they will not attain unless they resettle into planned towns with social bonds among neighbors, which is the fundamental principal of human urbanism." [2]

Franciscan and Dominican friars were among the principal bearers of the Hispanic concept of urban culture into the New World, as well as their evangelizing the new religious faith. Further analysis expands understanding: A major objective of the Spanish crown and many reformers, such as Bartolomé de las Casas, was assimilation and acculturation 
of non-European peoples into their urban culture. Franciscans and other religious orders founded numerous schools to implant the new faith among sons of the old nobility. Some of them also trained working-class indigenous males in new crafts and trades. In one example in this study, the founder of the new colonial city implanted alternatives to the normal feudal tributes in the colonies.

A range of colonial narratives describe how ordered urban design generated the colonial Spanish ideal of harmonious community. An example was ordinances by Tomás López Medel, an oidor, or justice from the colonial court, or audiencia, of Guatemala. He was sent to Yucatan as acting governor in c. 1550 . He ordered resettlement into planned new towns of Maya people who had lived in scattered rural settlements. The model for those new towns was houses of permanent construction in adjoining house lots, well-crafted churches, schools, inns for travelers, and "hospital houses" in each new town. The objective was to implant "temporal and spiritual urban culture (policía temporal y espiritual)". He states that he had already issued laws to give proper urban form in colonial settlements for Spaniards to give "[planned urban] form to Spaniards in their urban life (dar forma a los españoles en la vida politica)". Part of the temporal good for rural Mayas was generated by improved roads linking the towns, which were necessary for the "urban culture, trade, communication, conversation and commerce" among residents of different towns. For this author, the detailed description illustrates the harmonious community life cited by Durston. Urban design requirements are also cited in another narrative written in c. 1615 by the Dominican friar Antonio de Remesal who lived in Guatemala. He cited a program by the friars there to resettle rural Mayas in Guatemala in new towns with planned urban geometries, each with a central plaza, central church, town hall, an inn for travellers, with the rest of the lots surveyed in wide, rectilinear streets "in the form of [urban] blocks". The objective was to create an image of a "sociable township", or "república sociable", a term which, for this author, expands understanding of the theme of "harmonious community" cited by Durston. [3]

Many new Spanish towns and cities were superimposed over imposing pre-colonial urban/ ceremonial centers. A range of examples shows evidence that there was symbolic meaning: At actual conquests, such as Mexico City/ Tenochtitlán, non-European centers were typically demolished, erasing the memory of the old culture. In many others, especially urban centers in regions where Spanish rule was accepted peacefully, or where the residents actually became important allies of the Spaniards for their own reasons, selected geometrical patterns and architectural components were often retained. Examples suggest that it was a type of recognition of the pre-colonial cultural origins on the part of the Spaniards. Pre-colonial city-states were often at war with others; the alliances gave protection from ancient enemies.
This study examines two colonial capitals built by important allies of Cortes in Mexico/ New Spain: One was Tlaxcala, four confederated city-states in the mountains of central Mexico; the second was the Purépecha kingdom in Michoacán, in the highlands of west-central Mexico. In each, there were broad raised terraces associated with the old religions. My research shows clear evidence that the new colonial cities were carefully fitted around them in ways to recognize the old cultures and traditions and illustrate a respect for them, even as it redefined them with images and structures for the new faith. Broad platforms were retained as raised church yards, even as the old temples were demolished, and new churches and monasteries built with their stones. In each, programs were initiated to acculturate and assimilate Mesoamericans into the new colonial urban culture. They expand understanding of cultural interweaving which many Mexican scholars cite in their studies. The pattern was not limited to Latin America; in Alabama, two important Early Federal towns were platted around, or aligned with, significant Indian mounds. [4]

\section{The First Example Was Tlaxcala}

When Cortés's expedition arrived in central Mexico in c. 1519 , the four city-states had been under continuing seige for decades by the Aztecs who sought to conquer them and impose tributes, including many young males for human sacrifices. Walled palace compounds and tall temple pyramids dedicated to the principal gods and goddesses were built along the summits; the remaining citizens lived in tightly-built settlements fitted onto steep terraces, also defensible from Aztec attacks. [5] They were "scattered" rural settlements criticized by Mendieta later in the century. A visitor to the largest of the four cabeceras, named Ocotelulco, can see vestiges of relatively low terraces along the mountain top, apparently land for the upper status families; steep terraces then step down the mountain sides, apparently land for the working classes. The oldest city-state named Tepicticpac is the most vivid image of the pattern.

The Tlaxcalans initially fought Cortés, then there was a dialog and an alliance was made. Cortés was a guest in the prince's palace at Ocotelulco; he praised the urban culture: "... among [the Tlaxcalans] there is every manner of good order and urban life, and they are a people of reason and harmonious urban accordance" [6] The Tlaxcalan princes furnished a large army which was decisive in the conquest of Tenochtitlán. The Tlaxcalans then received significant privileges by the Spanish crown: They were exempt from most feudal tributes; the nobility had nominally accepted the new faith and agreed to send their sons to a school of the Franciscans, where they learned Spanish language and central themes in Hispanic culture; they were also taught the doctrines of the new faith, which they adopted with fervor. 


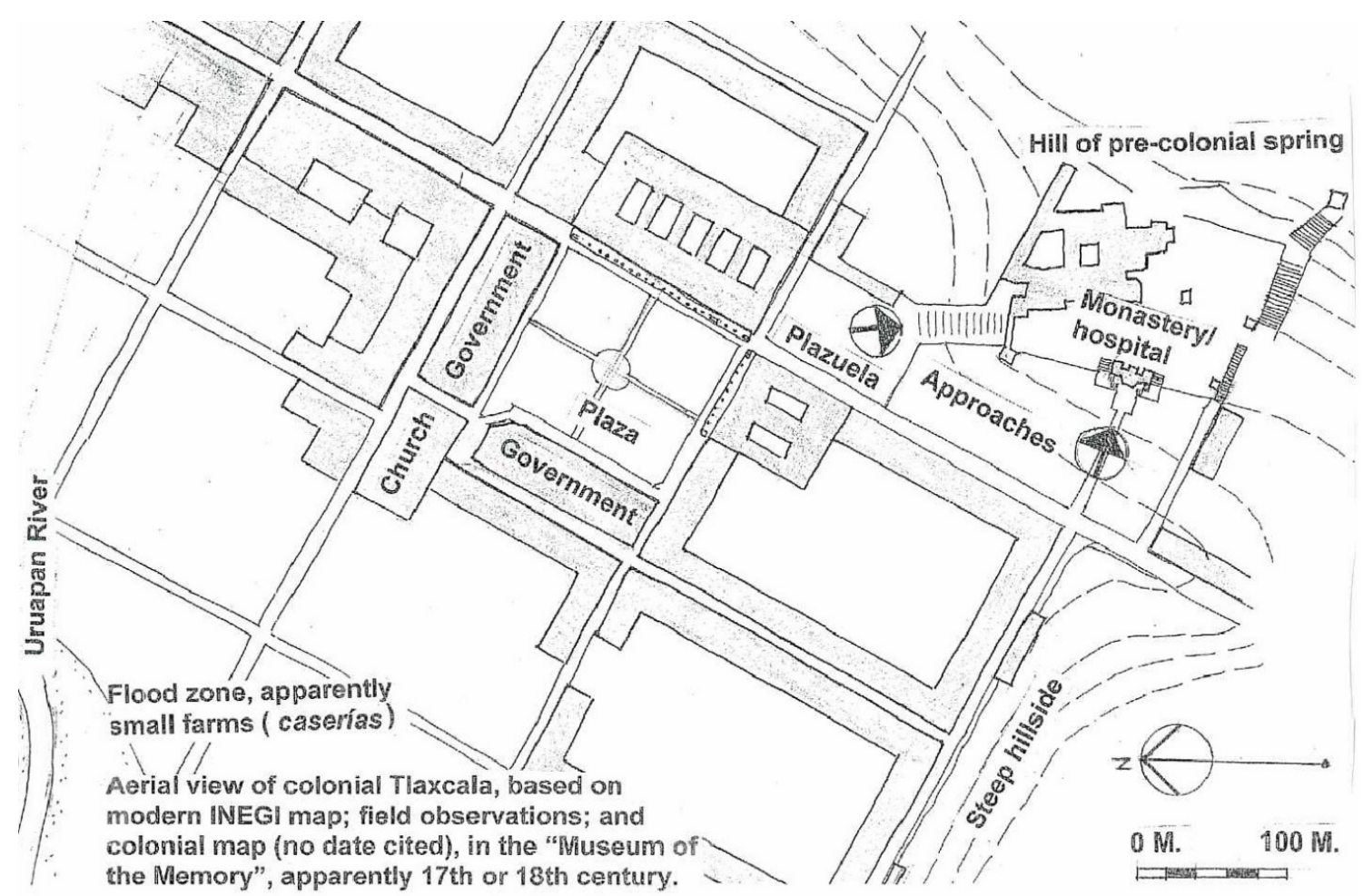

Figure 1. Reconstruction of 16th-century city center

Initially, the friars were only Spaniards allowed to settle in the province there. They arrived in c. 1523, a year cited by a Nahuatl history as when "the devils" houses" were demolished...". After 1550 epidemics greatly reduced the indigenous population, opening the province for additional Spanish settlers. For three years the friars lived in the same palace where Cortés had stayed; then a huge temple-pyramid nearby was demolished, and in c. 1527 the friars built an imposing monastery whose ruins are still visible. The friars had apparently accepted the non-European settlement pattern and tried to redefine it with a tall architectural image of the new faith. [7]

By c. 1528 the nobility, apparently led by sons who had been educated by the friars, decided to found a new Spanish-style city center, in a narrow river valley far below. It was the new provincial capital, clearly a response to the new peace and freedom from Aztec invasions. The builders wanted a city "in the Spanish mode"; Spanish objectives to acculturate non-Europeans were clearly implemented to a significant degree. A chronicle cites a "mutual consent" (consentimiento) among them for the urban project. [8]

A sixteenth-century friar cites 1537 as the date when the new city center was surveyed. The historian Muñoz Camargo states it was "the industry of the first friars", obviously the authors of the design.[9] It was a reticular street pattern, but not a modular Spanish checkerboard grid, with some variations from the Spanish model. The central plaza has a configuration unique in the New World: there is a pair of narrow blocks fitted around it, which housed major government buildings built in the mid-sixteenth century.

The most interesting characteristic is how the builders fitted the new city around two sides of a broad terrace overlooking the site, which was the site of a venerated spring used in pre-colonial rituals of purification: New-born babies were bathed; men (not women), bathed to atone for their sins; there were also human sacrifices. The chronicles do no cite a temple complex, but there is verbal evidence among Mexican archaeologists retain verbal evidence that vestiges of pre-colonial rampways were encountered in field work during the Mexican revolution, then recovered to protect them.[10] It was logically a grouping of raised platforms topped with temples, similar to other sites in the region. The builders then create a series of visually-dramatice spatial sequences which linked the city center with the old sacred spring site above. It recognized the ancient significance of the spring and at the same time redefined it with new architecture, an image of the succession of religious faiths, and an image of multi-cultural accordance.

In about 1538 or 1539 , the friars moved their central monastery down the mountain to the hill of the sacred spring. [11] It retained the old sacred site, but redefined it with new architecture, a visual image of the succession of religious faiths. They built a hospital; the school for Tlaxcalan youths was relocated there. Babies were still baptized; men and women atoned for sins; there were clearly no more human sacrifices. It created an upper precinct, overlooking the secular city center below. The two access ways echo some pre-colonial ramp ways at the pre-colonial palaces. As a note, the old spring head is still there, in a (locked) recess in the floor of the great former Franciscan monastic compound built on the site. 


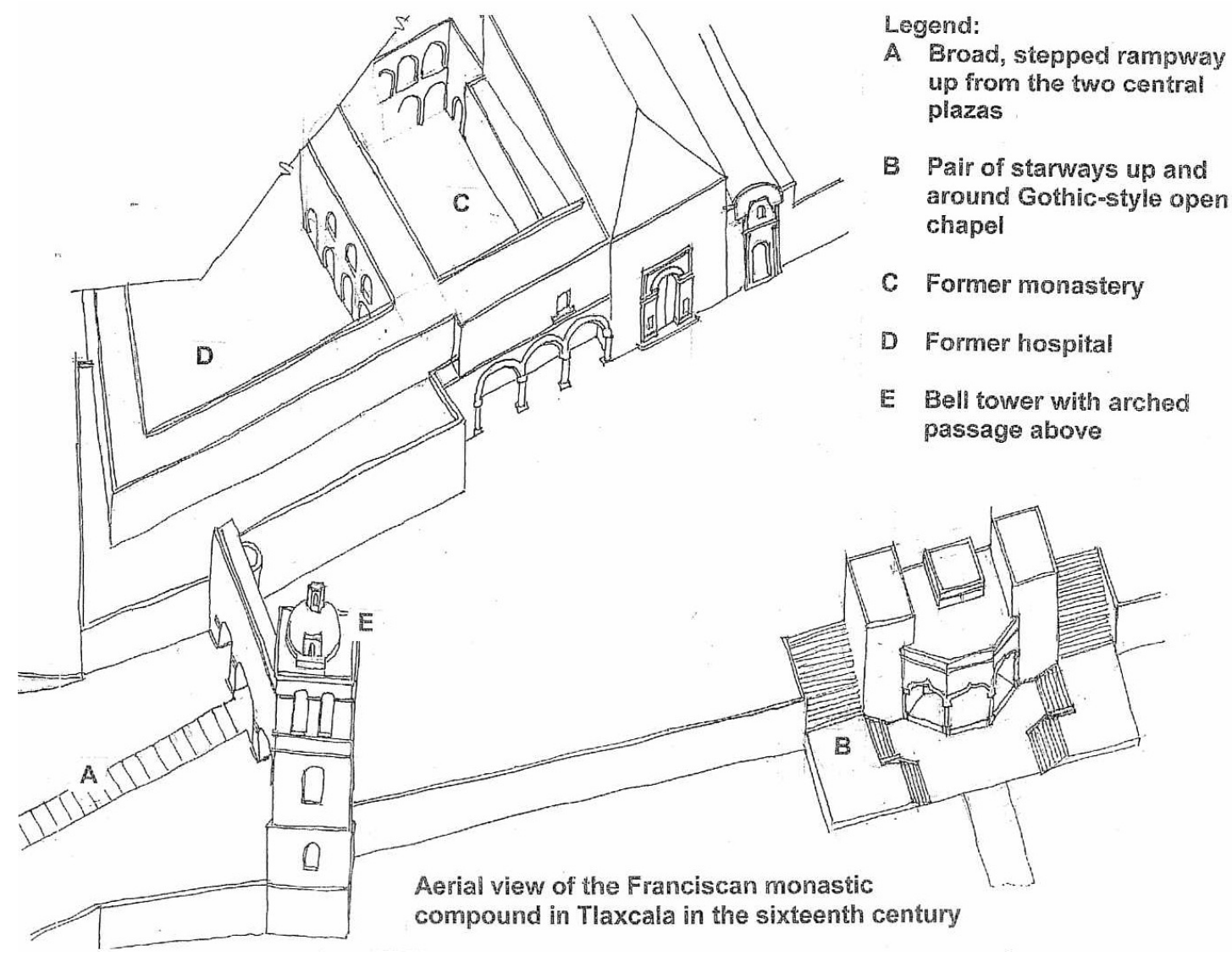

Figure 2. Franciscan compound in the city's upper precinct

By 1545 central core of the new secular city center had been built "in the Spanish mode", and clearly compatible with the pre-colonial concierto praised by Cortés, and an imposing New World example of Hispanic urbanism. The central plaza was lined with "grand and sumptuous" townhouses built by the nobility, and rows of imposing government buildings, creating an image of Spanish urbanism, with townhouses for the hidalgo class above and shops below, the culture of commerce and community which defined urban concierto. Most of the other residents of the upper townships transferred down to new barrios with "much order and concierto" on the surrounding hillsides overlooking the elite city center. Among them were "citizens" and "plebes", (ciudadanos y plebeyas), apparently residents of middle and tributary status. There was a settlement of caserias, or cottages for farm workers at one side of the elite central city, apparently for rural farmers who traded in the weekly market. [12]

The huge market visited by Cortés in c. 1519 was moved down to the new central plaza. It was given the royal title of "Ciudad Leal, or "Loyal City" in c. 1545, a great honor in the New World.[13] The flat valley below was quite small; the new barrios surrounding the level city center were built on hillsides, echoing the terraced, semi-fortified districts of the upper cabeceras.

The city plan is a reticular geometry but not a modular grid, with a range of block sizes. Many are significantly larger than blocks in other Spanish cities surveyed in the first half of the sixteenth century. As a note, many blocks were subdivided at a later date, possibly widening existing alleys. There is no data expanding on the friars' image of urbanism; one thing is clear: It created the urban life of concierto.

\section{The Second Example, Pátzcuaro, Michoacán}

Pátzcuaro, located in the west-central highlands of Mexico, was another imposing pre-colonial urban center which was reshaped and redefined in the 1540 s to create a seat for a new cathedral and provincial capital. It had once been a royal capital of the pre-colonial Purépecha kingdom, whose king became another vital ally of Cortés in defeating the Aztecs. That alliance was severely threatened when an expedition by Nuño de Guzmán, a Spanish military captain, led an expedition through the region, demanded gold from the king, then murdered him when he did not satisfy his demands. [14] The reformist colonial supreme court sent an idealistic attorney named Vasco de Quiroga into the region. His skills at diplomacy restored the alliance; he was then named bishop of the new province, where he began construction of a cathedral in the existing royal capital of Tzintzuntzan, a small urban center overlooked by a group of massive temples pyramids. The old priests opposed the new faith; allies of the 
old priests harassed the new church services. Sunlight was limited and there were other ecological factors.

In c. 1540 Quiroga then transferred the cathedral seat to the mostly-abandoned urban site of Pátzcuaro. It had a legendary significance among the Purépechas. Centuries before, Purépechas had settled in the lake region. A group of them came to a rocky place on a tall hillside with large rocks and a spring of water. A king later stated that it was the doorway to heaven through which the dieties came and went, the only such place in the universe.[15] They leveled part of the terrain to create broad platform and built three temples and three houses for the old priests. On level terrain below the kings built a royal palace retreat with a botanical garden and apparently a zoo, all of it irrigated from that spring. In the 1530s it was abandoned after a rebellious prince and his daughter Erendira launched a battle to expel the Spaniards, but were then defeated and most of the residents fled.

After selecting the site for the new cathedral seat, Quiroga designed the new colonial city. He had concepts of ideal urbanism; he had read Sir Thomas More's work Utopia, and had communicated with More.[16 ]

He had previously designed a series of small "hospital towns "hospital-pueblos, townships with communal hospitals, where the native families were exempt from tributes of labor or goods to the encomenderos if they donated time or food; there were communal gardens and self-help programs for residents, programs clearly calculated to generate a concierto among them.[17] Residents of the town of Santa Fe de la Laguna still cherish his memory and cite him as "Tata", or "grandfather", Vasco.

Francisco Ramírez, the rector of the seminary and finishing school founded by Quiroga cites Quiroga's reasons for selecting Pátzcuaro: Quiroga had "viewed the grandeur" of the ruined structures and they "moved him to found the cathedral at that site", in order that what had been the "metropolis of the old faith" would become the seat for the new faith and "illuminate it". [18]

Archaeologists have identified a tiny apartment fitted into the vestiges of the ancient walls stepping up from behind the former seminary as the modest dwelling of Quiroga; adjacent to it in the street is the ancient spring which led the first Purépecha settlers to found a city at that site.[19] It clearly illustrates a desire by Quiroga to retain a memory of the old urbanism as part of the new urban overlay. It strongly suggests that his vision of the new city was to be in accordance ("de acuerdo") with the traditions and urban form of the old culture.

Quiroga laid out the new city and then populated it with a large group of settlers to the new city. They included twenty-eight Spanish families, transferred from the old capital at Tzintzuntzan, apparently of middle and working class status. [20] Others included a significant group of the Purépecha nobility including the son of the murdered king, as well as a large population of rural Purépechas of tributary status.
Legend:

A Final cathedral

B Provisional cathedral

C Former finishing school of San Nicolás

D Principal plaza

E Colonial houses with courtyard gardens

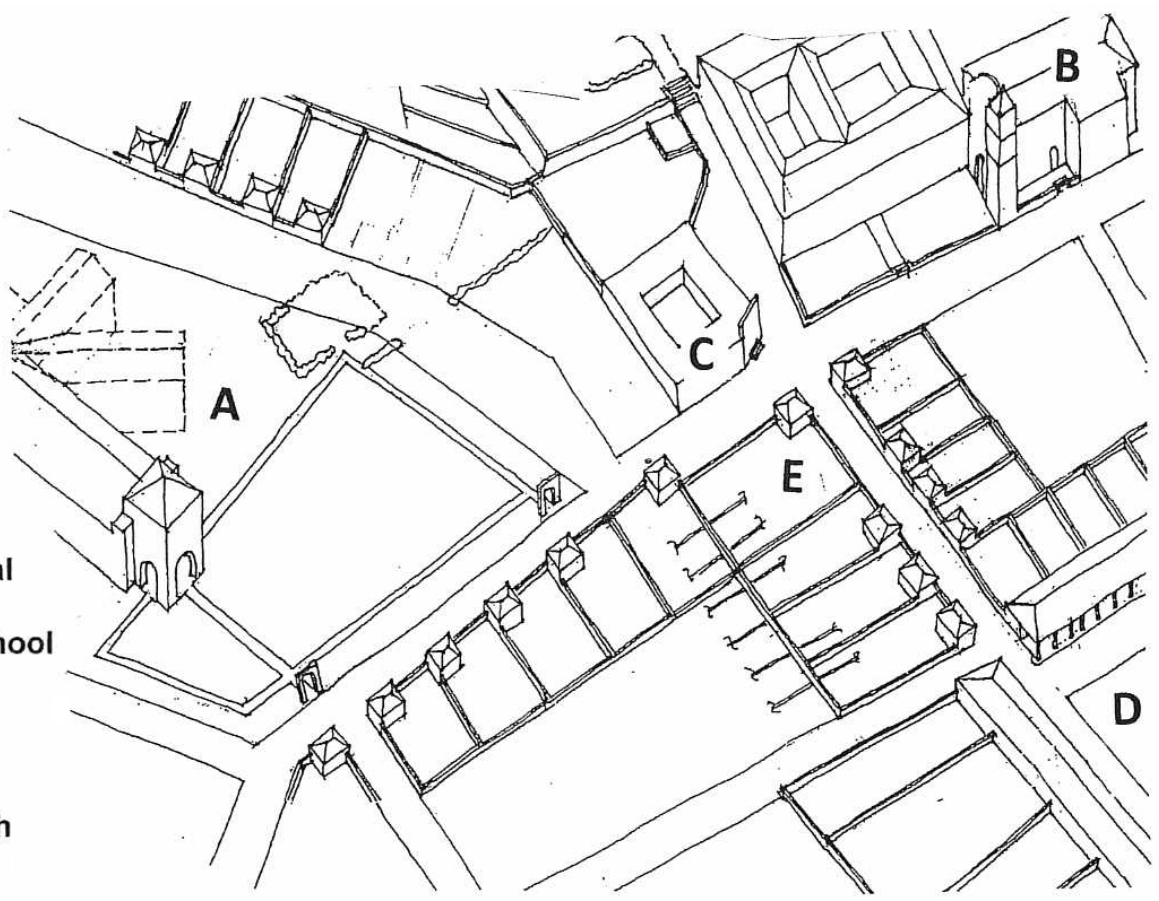

Aerial view of Pátzcuaro in the sixteenth century: Hypothetical reconstruction

Figure 3. Reconstruction of 16th-century city center 
Quiroga fitted an ordered urban grid around the great pre-colonial platform. It was an urban design with distinct upper and lower precincts. Above, along the grand Purépecha temple platform, he built a provisional cathedral, a seminary for Spanish and Purépecha males, a hospital, and later the final cathedral, a nun's convent and a Jesuit monastery. The lower precinct was the secular city, with a central plaza, platted over the old kings' retreat. Most lots facing the central plaza were granted to the Purépecha nobles; the mansion of the old king's son is still a prominent landmark facing the plaza. Many of the nobles apparently rented the lower floors of their two-story townhouses to middle-class Spanish traders and merchants, and they, and not encomenderos, were the initial Spanish presence in the new colonial capital. The rural and tributary class Purépecha families were settled in new, planned barrios adjacent to the elite central core, and laid out adjacent to monasteries for Franciscans and Augustinians; they were assigned in repartimiento to the friars of the two monasteries. Residents of the new city practiced many trades and professions, including merchants, colonial officials, blacksmiths, boiler makers, and others.[21]

The city center which emerged from Quiroga's planning and design was an image of concierto, or a harmonious urban community. His projects also had societal objectives: They were focused on assimilation and acculturation of the non-European people. Other communitarian services include exemptions from feudal tributes as in the other hospital-towns. In a legal document Quiroga stated that he had "settled the new citizens in order and urban civility, in order that the Mesoamerican peoples should be favored.[22] There were a series of characteristics in the new city which implanted a powerful image of the new urbanism and generated interaction among residents across class and culture lines. First, the new secular plaza was laid over the old king's botanical garden and zoo. The private royal retreat was superseded by an urban space accessible to all people. Second, the row of temples and priestly residence atop the grand upper terrace were apparently restricted to an elite class, who demanded material displays of wealth and power to appease the old gods and goddesses. The new image replaced them with a range of structures to offer human services to the community as well as the new religious faith.

Quiroga also designed a series of urban spaces that encourage interaction among all the citizens of the working-class barrios, the central plaza, and the upper precinct with its row of churches, and communitarian services. A series of visual axes were laid out in the secular city below and extended up to the upper precinct. Some of those visual sequences lead from plazas below to tall facades above. It attracts pedestrian movement from the urban spaces below to the upper precinct. Another series of those vistas appears to generate pedestrian movement among the lower barrios and the secondary plazas. It appears to generate the urban interaction across lines of cultural origins and personal wealth and status. Later in the century Spaniards of the encomendero class succeeded in transferring the capital to still another site, Morelia, because they felt that bishop Quiroga was neglecting them in favor of the native peoples.

\section{Conclusions}

In summary, in each of the two examples ordered urban plans were inserted over existing non-European urban centers. The pre-colonial configurations were each quite different from the Spanish urban model. Retention of the seats of the ancient temples overlooking the ordered colonial urban geometries was a significant feature in both examples. In each example, choice of the non-European ceremonial centers as seats for the new colonial city centers was apparently based, at least in part, on recognition of the pre-colonial cultures and an accordance with the non-European culture and urban form. The analysis expands understanding of how the two variations of the typical reticular grid model were apparently planned as parts of the image of ordered urban geometries. For a modern researcher, they appear to create a pair of distinctive images of concierto, or harmonious urbanism cited in the chronicles. It is useful data for a broader analysis of Spanish responses to major non-European urban sites in the New World as they implanted their urban culture in the sixteenth century.

\section{Endnotes}

1. Durston cites harmonious community, 86 .

2. Mendieta, 136.

3. Remesal cites the "república sociable", II: 243; Cogolludo quotes the urban design ordinances of Tomás López Medel, V:390-403.

4. Cited on historical markers at Cahaba, briefly a state capital, and Florence, Alabama.

5. Muñoz Camargo, 41-42.

6. Cortés, "Segunda Relación", 33.

7. Townsend cites the Nahuatl history, 161. Gibson cites the epidemics after 1550, 149. Gibson cites the date of construction for the first monastic compound in Ocotelulco, 44.

8. Gibson cites the date for founding the new city of Tlaxcala in the valley below, 125. Muñoz Camargo cites the desire for a city in the modo castellano and the mutual consent among the Tlaxcalan nobility, 43.

9. Motolinia cites 1537 as date of the city survey, cited in Cuellar Bernal, 46. Muñoz Camargo cites the authors of the urban plan, 43.

10. Muñoz Camargo cites the ancient rites, 55-56. The INAH Archaeologist Hugo Sánchez cited a verbal record of ancient rampways, in a personal conversation with this author in 2006.

11. Gibson, 45.

12. Muñoz Camargo cites the new city center and states it 
generated orden y concierto, 43 . He cites the settlement of caserías, 66.

13. Cited by Peñafiel, 152.

14. Abuses by Nuño de Guzmán are cited by Beaumont, T.II: $178-182$.

15. Craine \& Reindorp, 120-121.

16. Závala cites Quiroga's praise for More, and evidence that More's writing influenced him, 230-232.

17. Závala cites the hospital towns, 15 .

18. Ramírez, 68.

19. Data from a conversation w/ Prof. Casales at INAH, Pátzcuaro, in c. 2012.

20. Salas León, 19.

21. Warren cites the first two monastic compounds in Michoacán en la década de 1580, 43. Acuña cites the trades in the new city, 202.

22. Beaumont, T. III: 269.

\section{REFERENCES}

[1] Acuña, René, ed. Relaciones Geográficas del Siglo XVI: Michoacán, Instituto de Investigaciones Antropológicos, Serie Antropológico, Universidad Autónoma de México, Mexico, D.F., 1987.

[2] Azevedo Salomao, Eugenia María. Espacios urbanos comunitarios durante el periodo virreinal en Michoacán, Morrevallado Editoriales, Morelia, Mich., 2003

[3] Beaumont, Fr. Pablo. Crónica de Michoacán, Republ. Talleres Gráficos de la Nación, Mexico, D.F., 1932.

[4] Cogolludo, Fray Diego López de, Los tres siglos de la dominación española en Yucatán o sea historia de esta provincia, repub. Academische Druck, Graz, Austria repub 1971.

[5] Cortés, Hernán. Cartas de Relación, Tercera Edicion. Republ. Editorial Porrúa, S.A. Mexico, D.F., 1967.

[6] Cuellar Bernal, René. Tlaxcala a través de los Siglos, Mexico, D.F., 1968.
[7] Durston, Alan. "Un Regimen Urbanístico en la América Hispana Colonial: El Trazado en Damero durante los Siglos XVI y XVII", in Historia, Vol. 28, Santiago de Chile, 1994.

[8] Gibson, Charles. Tlaxcala in the Sixteenth Century, Yale University Press, New Haven, CT., 1952.

[9] López Sarrelangue, Delfina Esmiralda. La nobleza indígena de Pátzcuaro en la época virreinal , Universidad Nacional Autónoma de México, Instituto de investigaciones históricas,, Mexico, D.F., 1965.

[10] Mendieta, Fray Gerónimo de. "Codice Mendieta", in Nueva Colección de Documentos para la Historia de México. Publ. Joaquín García Icazbalceta,, republ. Kraus Reprint, Nedeln, 1971.

[11] Muñoz Camargo, Diego. Relaciones Geográficas de Tlaxcala, republ., Gobierno del Estado de Tlaxcala, Tlaxcala, Mex., Segunda Edicion, 1999.

[12] Peñafiel, Antonio. La Ciudad Virreinal de Tlaxcala, Editorial Cosmos, Mexico, D.F., 1978.

[13] Ramírez, Francisco, El Antiguo Colegio de Pátzcuaro, Republ. El Colegio de Michoacán, Gobierno del Estado de Mich., Morelia, Mich., 1987.

[14] Remesal, Fr. Antonio de. Historia General de las Indias Occidentales y Particular de la Gobernación de Chiapa y Guatemala, Tomo I, Republ. Editorial Porrúa, S.A., Mexico, D.F., 1988 .

[15] Salas León, Antonio. Pátzcuaro, Cosas de Antaño y de Hogaño, Segunda Ed., Morelia, Michoacán, 1956.

[16] Thompson, J.Eric, edit. w/ introd. Thomas Gage's Travels in the New Worldl. University of Oklahoma, Norman, 1958.

[17] Townsend, Camilla, edit. And transl. Here in this Year Seventeenth-Century Nahuatl Annals of the Tlaxcala-Puebla Valley, Stanford University Press, Stanford, CA, 161).

[18] Warren, J. Benedict Michoacán en la década de 1580, Universidad Michoacana de San Nicolás de Hidalgo, Centro de Investigaciones Históricas, Morelia, Mich., 2000.

[19] Závala, Silvio. Recuerdo de Vasco de Quiroga, Editorial Porrúa, México, D.F., 1997. 